\title{
Enhanced Steroid Metabolites Production by Resting Cell Phytosterol Bioconversion
}

\author{
X.-Q. Gao, J.-X. Feng, X.-D. Wang, ${ }^{*}$ Q. Hua, and D.-Z. Wei ${ }^{\#}$ \\ State Key Laboratory of Bioreactor Engineering, Newworld Institute \\ of Biotechnology, East China University of Science and Technology, \\ 130 Meilong Road, Shanghai 200237, China
}

doi: 10.15255/CABEQ.2014.2098

Original scientific paper

Received: August 26, 2014

Accepted: November 24, 2015

The steroid metabolites 9-hydroxy-androstenedione (9-OH-AD), androstadienedione (ADD) and androstenedione (AD) are important steroidal pharmaceuticals. In order to raise the production of steroid metabolites, an efficient resting cell phytosterol bioconversion process was developed to produce $9-\mathrm{OH}-\mathrm{AD}$ in the presence of hydroxypropyl- $\beta$-cyclodextrin (HP- $\beta$-CD). Cell growth medium containing phytosterol as an inducer positively improved cell activity. Under aerobic conditions, bioconversion proceeded at $70 \mathrm{~g} \mathrm{~L}^{-1}$ phytosterol in the presence of HP- $\beta$-CD (the optimized molar ratio of HP- $\beta$-CD/phytosterol was $1: 1$ ) with $30 \mathrm{~g} \mathrm{~L}^{-1}$ resting Mycobacterium neoaurum NwIB-yV cells (cell dry mass) in a 5-L bioreactor, where 9-OH-AD production and space-time yield reached $36.4 \mathrm{~g} \mathrm{~L}^{-1}$ and $9.1 \mathrm{~g} \mathrm{~L}^{-1} \mathrm{~d}^{-1}$, respectively. The recycling of cells and HP- $\beta$-CD enables cost-saving and industrial applications. This bioprocess was also applied for the production of ADD and AD. The production of these steroid metabolites was much higher than that reported in previous studies.

Key words:

phytosterol, steroid metabolites, resting cell bioconversion, hydroxypropyl- $\beta$-cyclodextrin, optimization

\section{Introduction}

Microbial sterol bioconversion is a powerful approach for the production of key steroidal intermediates, such as 9-hydroxy-androstenedione (9-OH-AD), androstadienedione (ADD) and androstenedione (AD). These steroid metabolites are valuable starting materials for the preparation of steroidal pharmaceuticals which are widely used as anti-tumor, anti-inflammatory, anti-microbial, anti-viral, and anti-fungal drugs, etc. ${ }^{1} \mathrm{AD}$ and ADD are required for the commercial production of corticosteroids, mineralocorticoids, oral contraceptives, and other pharmaceutical steroids. 9-OH-AD is an important precursor for manufacturing glucocorticoid drugs bearing a halogen in position $9 \alpha .^{2-4}$ However, microbial sterol bioconversions are typically low-efficiency reactions, largely owing to the poor water solubility of sterol, resulting in a major bottleneck that impedes the development of practical applications. Many approaches have been taken to improve the solubility and bioavailability of sterols to the bacteria and increase the efficiency of microbial sterol bioconversion, including the use of the cyclodextrin $(\mathrm{CD})$ complexation technique ${ }^{5}$ and

"Corresponding authors: Xue-Dong Wang: Tel.: +86 02164253715 ,

Fax: +8602164250068, E-mail address: xdwang@ecust.edu.cn;

Dong-Zhi Wei: Tel.: +86 021 64252078, Fax: +86 02164250068 ,

E-mail address: dzhwei@ecust.edu.cn applications of two-phase systems with an organic solvent ${ }^{6}$ or silicone oil. ${ }^{7}$ However, the use of organic solvents with microbial systems is disadvantageous, given that organic solvents are frequently toxic to microbial cells and pose environmental hazards. ${ }^{5}$ Silicon oil also inhibits microbial cell growth, ${ }^{7}$ thus also making it a suboptimal choice for the production of steroid metabolites.

CDs have a doughnut-shaped molecular structure, with a hydrophilic outer surface and a hydrophobic cavity. ${ }^{8}$ CDs and their derivatives can form host-guest complexes with hydrophobic compounds in their internal cavities. The hydrophilic outer surface of inclusion complexes increases the bioavailability of hydrophobic compounds to microorganisms. ${ }^{9}$ Hydroxypropyl- $\beta$-cyclodextrin (HP- $\beta$-CD), a $\mathrm{CD}$ derivative, has a greater capacity for complex formation than $\mathrm{CD}$, and it has been recently used for the bioconversion of phytosterol to ADD and AD. ${ }^{5,10}$

Recently, it was demonstrated that the bacterial strain Mycobacterium neoaurum NwIB-yV can be used in transforming phytosterol to 9-OH-AD. ${ }^{11}$ The production of 9-OH-AD and the associated space-time yield reached $7.33 \mathrm{~g} \mathrm{~L}^{-1}$ and $1.22 \mathrm{~g} \mathrm{~L}^{-1} \mathrm{~d}^{-1}$, respectively, from $15 \mathrm{~g} \mathrm{~L}^{-1}$ phytosterol in an aqueous system using growing $M$. neoaurum NwIB-yV cells, indicating a high potential for industrial appli- 
cations. However, the presence of silicon oil introduces difficulties in downstream processing and purification, beyond its cell growth limiting effect.? In addition, this process was based on the bioconversion of sterols in growing cultures, where low cell densities and high complexity limited substrate (phytosterol) concentration and process productivity. The use of resting cell bioconversion with a previously grown population of cells provides an efficient method for running bioprocesses at high cell density. ${ }^{12}$

In terms of potential industrial applications, a great demand exists for the development of novel high-efficiency bioconversion processes producing 9-OH-AD or other steroid metabolites. In this work, we studied the effects of substrate solubilization with HP- $\beta-\mathrm{CD}$ and the use of resting cell bioconversion on the conversion of a high concentration of phytosterol to 9-OH-AD. Bioconversion process optimization and recycling capacity for cost savings, especially that of HP- $\beta$-CD, were discussed.

\section{Materials and methods}

\section{Strains and medium}

Mycobacterium neoaurum NwIB-yV (genetic final type: KstD inactivated; KshA1 and ChoM2 augmented; ATCC 25795 derivant) was developed by Yao et al. and produces $9-\mathrm{OH}-\mathrm{AD}$ as the major product from phytosterol. ${ }^{11}$

M. neoaurum NwIB-yV was activated in medium MYC/01 as seed culture $\left(\mathrm{H}_{2} \mathrm{O} 1 \mathrm{~L}\right.$, glycerol 20 $\mathrm{g}$, citric acid $2 \mathrm{~g}$, ammonium ferric citrate $0.05 \mathrm{~g}$, $\mathrm{K}_{2} \mathrm{HPO}_{4} \cdot 3 \mathrm{H}_{2} \mathrm{O} 0.5 \mathrm{~g}, \mathrm{MgSO}_{4} \cdot 7 \mathrm{H}_{2} \mathrm{O} 0.5 \mathrm{~g}, \mathrm{NH}_{4} \mathrm{NO}_{3}$ $2.0 \mathrm{~g}, \mathrm{pH}$ value 7.5$).{ }^{13}$ The growth medium $\mathrm{MYC} / 03$ was prepared by dissolving $20 \mathrm{~g}$ of glucose, $2 \mathrm{~g}$ of citric acid, $0.05 \mathrm{~g}$ of ammonium ferric citrate, $0.5 \mathrm{~g}$ of $\mathrm{K}_{2} \mathrm{HPO}_{4} \cdot 3 \mathrm{H}_{2} \mathrm{O}, 0.5 \mathrm{~g}$ of $\mathrm{MgSO}_{4} \cdot 7 \mathrm{H}_{2} \mathrm{O}$, and $1 \mathrm{~g}$ of corn steep powder in $1 \mathrm{~L}$ of $\mathrm{H}_{2} \mathrm{O}$ and adjusting the $\mathrm{pH}$ value to 8 .

\section{Reagents}

A mixture of phytosterol containing $\beta$-sitosterol, campesterol, stigmasterol, and brassicasterol (47.5: 26.4: 17.7: 3.6, by weight, respectively) was purchased from Davi Biochemistry, Inc. (Huzhou, China). The steroid metabolites 9-OH-AD, ADD and AD were obtained from Sigma (St. Louis, MO, USA). HP- $\beta$-CD was purchased from RSC Chemical Industries Co. Ltd. (Kunshan, China). Corn steep powder was obtained from Xiwang Group Co. Ltd. (Binzhou, China). Other chemicals were analytical reagents.

\section{Cell culture, harvesting and resting cell bioconversion}

After activation of the culture of $M$. neoaurum NwIB-yV in MYC/01 medium $(50 \mathrm{~mL}$ in $250 \mathrm{~mL}$ shake flasks) for 2 days at $30{ }^{\circ} \mathrm{C}$ and $200 \mathrm{rpm}, 10 \%$ $(\mathrm{v} / \mathrm{v})$ culture broths were inoculated in $300 \mathrm{~mL}$ cell growth medium MYC/03 in 1000-mL shake flasks containing $0.1 \mathrm{~g} \mathrm{~L}^{-1}$ phytosterol. After 3 days of growth at $30{ }^{\circ} \mathrm{C}$ and $200 \mathrm{rpm}$, the cells were harvested by centrifugation, washed 2 times with $20 \mathrm{mM}$ phosphate buffer ( $\mathrm{PB}, \mathrm{pH}$ value 8$)$, and stored as a wet cell paste at $-20^{\circ} \mathrm{C}$ until used for bioconversion.

The model bioconversion process with resting $M$. neoaurum NwIB-yV cell was performed in $15 \mathrm{~mL}$ PB (20 mM, pH value 8) under non-sterile conditions, containing $15 \mathrm{~g} \mathrm{~L}^{-1}$ cell dry mass (CDM) and $50 \mathrm{~g} \mathrm{~L}^{-1}$ phytosterol at a $1: 1$ molar ratio of $\mathrm{HP}-\beta-\mathrm{CD} /$ phytosterol in a $250-\mathrm{mL}$ flask at $30^{\circ} \mathrm{C}$ and $200 \mathrm{rpm}$. The bioconversion of phytosterol was performed in triplicate.

The optimization procedure was performed as described below. Different HP- $\beta$-CD/phytosterol molar ratios $(2: 1,1: 1$ and $1: 2)$ were investigated to determine the optimal HP- $\beta$-CD concentration; different phytosterol concentrations $(0,0.01,0.05,0.1$, 0.5 and $1 \mathrm{~g} \mathrm{~L}^{-1}$ ) were added to the cell growth medium MYC/03 as an inducer to obtain the highest resting cell activity; multilevel analyses of resting cells and phytosterol concentration were investigated to maximize the 9-OH-AD space-time yield.

After optimization, the bioconversions were performed under aerobic conditions in a 5-L bioreactor (Shanghai BaoXing Bio-Engineering Equipment Co. Ltd., China; equipped with a 6-blade turbine impeller) at $30{ }^{\circ} \mathrm{C}$ in 2 -L reaction volumes containing an optimal resting cell density and phytosterol concentration (1:1 HP- $\beta$-CD/phytosterol molar ratio). Dissolved oxygen was maintained at $30 \%$ air saturation by automatically varying the agitation speed. The aeration rate was set at $2 \mathrm{~L} \mathrm{~min}^{-1}$ air.

After bioconversion, M. neoaurum NwIB-yV cells were harvested by centrifugation, washed 2 times with PB and recycled for subsequent bioconversion reactions. Supernatants were extracted with ethyl acetate to recover the product. HP- $\beta$-CD solution (aqueous phase) was evaporated to remove residual ethyl acetate and then used for subsequent bioconversion.

\section{Steroids analysis}

Thin layer chromatography was used to monitor the resting cell bioconversion process. Samples of reaction broth $(0.1 \mathrm{~mL})$ were extracted with $0.4 \mathrm{~mL}$ of ethyl acetate for 5 minutes in Eppendorf centrifuge tubes, and centrifuged at $8600 \mathrm{~g}$ for 5 minutes. Subsequently, $0.01 \mathrm{~mL}$ of the ethyl acetate fraction was applied to HSGF254 plates (Qingdao Marine Chemical Factory, China), developed in 
petroleum ether $\left(60-90^{\circ} \mathrm{C}\right) /$ ethyl acetate $(6: 4, \mathrm{v} / \mathrm{v})$, and visualized with $20 \%$ sulfuric acid solution by heating at $110{ }^{\circ} \mathrm{C}$ for 15 minutes.

Ethyl acetate fractions were also prepared for analysis by high-performance liquid chromatography (HPLC) by evaporating $0.1 \mathrm{~mL}$ of ethyl acetate fractions and dissolving them in $0.8 \mathrm{~mL}$ of methanol. Steroid metabolites were analyzed by HPLC (Agilent Technologies, Inc., Santa Clara, CA, USA) on a Hypersil ODS2-column (5 $\mu \mathrm{m}, 4.6 \times 250 \mathrm{~mm}$; Elite, China) at $40{ }^{\circ} \mathrm{C}$, with UV detection at $254 \mathrm{~nm}$. The flow rate of the mobile phase composed of methanol/water $(70: 30, \mathrm{v} / \mathrm{v})$ was $1 \mathrm{~mL} \mathrm{~min}^{-1}$. The retention times of 9-OH-AD, ADD and AD were 3.9, 4.4 and 5.2 minutes, respectively. Peaks were compared to those of 9-OHAD, ADD, AD internal standard to quantitate product formation during phytosterol bioconversion.

\section{Results and discussion}

\section{HP- $\beta$-CD solubilization and HP- $\beta$-CD/phytosterol molar ratio optimization}

Due to the hydrophobic characteristic of phytosterol, the solubility is low in aqueous solutions, which results in a poor availability of the substrate. During the resting cell bioconversion process, 9-OH-AD production was very low in the absence of $\mathrm{HP}-\beta-\mathrm{CD}$, with a peak $9-\mathrm{OH}-\mathrm{AD}$ production of only $3.2 \mathrm{~g} \mathrm{~L}^{-1}$ (Fig. 1). Induction of HP- $\beta$-CD had been shown to be the most effective means of enhancing sterol bioconversion at suitable molar ratios in growing cell cultures..$^{5,9,14}$ In this study, 9-OH-AD production was greatly improved following phytosterol solubilization with HP- $\beta$-CD. Fig. 1 shows the effect of varying the $\mathrm{HP}-\beta-\mathrm{CD} /$ phytosterol molar ratio on the time course of $9-\mathrm{OH}-\mathrm{AD}$

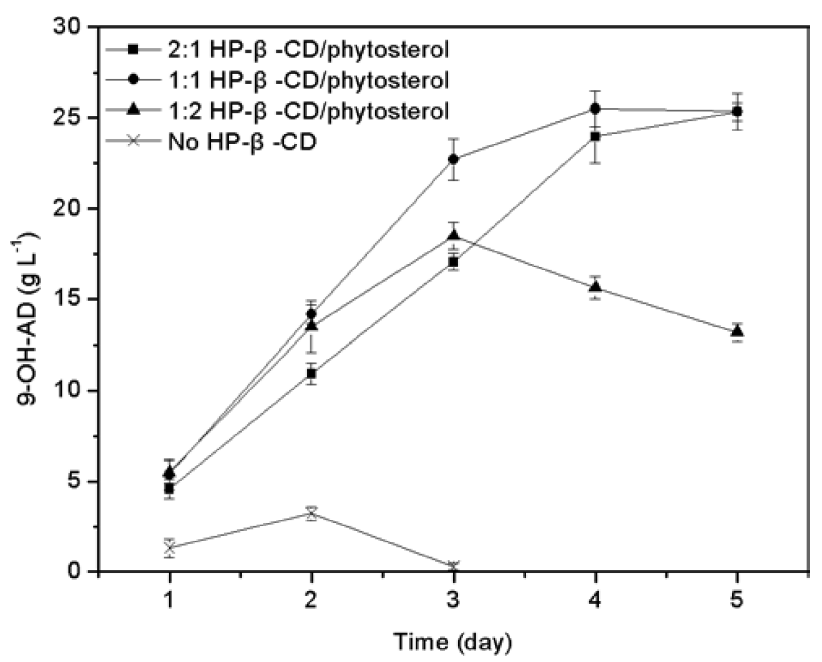

Fig. 1 - Effects of HP- $\beta-C D /$ phytosterol molar ratios on resting cell bioconversion with $50 \mathrm{~g} \mathrm{~L}^{-1}$ phytosterol and $15 \mathrm{~g} \mathrm{~L}^{-1} \mathrm{CDM}$ production with resting cell bioconversion reactions. Maximum production was achieved using an $\mathrm{HP}-\beta-\mathrm{CD} /$ phytosterol molar ratio of $1: 1$. Use of a higher $\mathrm{HP}-\beta-\mathrm{CD} /$ phytosterol molar ratio $(2: 1)$ resulted in a lower reaction rate, which may be attributed to a corresponding decrease in the concentration of free phytosterol. At a limiting HP- $\beta$-CD concentration (1:2 HP- $\beta$-CD/phytosterol molar ratio or no HP- $\beta$-CD), product degradation usually can be detected because of the nucleus degradation. It was obvious that the formation of the CD-steroids inclusion complex inhibited the degradation of sterols nucleus. This result was in agreement with a study by Khomutov et al., who showed that incorporation of 9-OH-AD into 9-OH-AD-MCD (methylated- $\beta$-cyclodextrin) inclusion complexes protected it from enzymatic degradation. ${ }^{15}$

\section{Optimization of concentrations of phytosterol inducers in cell culture}

In addition to phytosterol solubilization, the reaction rates in resting cell bioconversion also depend upon cellular enzymatic activities. In contrast to bioconversion performed with actively growing cells, a distinguishing feature of resting cell bioconversion is that the optimization of cell culture and resting cell bioconversion processes can be performed individually. In addition, 4 groups of catabolic enzymes involved in sterol bioconversion are inducible, such as the $\omega$-oxidase reaction and a methyl-crotonyl-CoA carboxylase system. Sitosterol or campesterol can be used as inducers. ${ }^{16}$

In this work, various phytosterol concentrations were added to $1-\mathrm{L}$ flasks containing $300 \mathrm{~mL}$ of cell growth medium MYC/03 to establish optimal induction conditions. As shown in Table 1, the specific cellular activity $\left(Y_{\mathrm{P} / \mathrm{X}}\right)$ increased with increasing inducer

Table 1 -Effect of phytosterol concentration as inducer on cells activity. M. neoaurum NwIB-yV cells were harvested on day 3 and used for resting cell bioconversion using $15 \mathrm{~g} \mathrm{~L}^{-1} C D M$, $50 \mathrm{~g} \mathrm{~L}^{-1}$ phytosterol, and a 1:1 molar ratio of HP- $\beta-C D /$ phytosterol.

\begin{tabular}{c|c|c|c}
\hline $\begin{array}{c}\text { Phytosterol } \\
\left(\mathrm{g} \mathrm{L}^{-1}\right)\end{array}$ & $\begin{array}{c}X^{\mathrm{a}} \\
\left(\mathrm{CDM} \mathrm{g} \mathrm{L}^{-1}\right)\end{array}$ & $\begin{array}{c}Y_{\mathrm{P} / \mathrm{b}}^{\mathrm{b}} \\
\left(\mathrm{g} \mathrm{g}^{-1} \mathrm{CDM}\right)\end{array}$ & $\begin{array}{c}Y_{\mathrm{P}}^{\mathrm{c}} \\
\left(\mathrm{g} \mathrm{L}^{-1}\right)\end{array}$ \\
\hline 0 & $4.7 \pm 0.2$ & $1.2 \pm 0.1$ & $5.6 \pm 0.1$ \\
0.01 & $4.6 \pm 0.1$ & $1.5 \pm 0.1$ & $6.9 \pm 0.1$ \\
0.05 & $4.5 \pm 0.2$ & $1.6 \pm 0.1$ & $7.2 \pm 0.1$ \\
0.1 & $4.4 \pm 0.1$ & $1.7 \pm 0.1$ & $7.5 \pm 0.1$ \\
0.5 & $4.1 \pm 0.2$ & $1.8 \pm 0.1$ & $7.4 \pm 0.1$ \\
1 & $4.0 \pm 0.1$ & $1.8 \pm 0.1$ & $7.2 \pm 0.1$
\end{tabular}

${ }^{\mathrm{a}} X$ (Cell dry mass, CDM): Harvested cell biomass

${ }^{\mathrm{b}} Y_{\mathrm{P} / \mathrm{X}}$ (Specific cellular activity): g 9-OH-AD per g harvested cell biomass

${ }^{\mathrm{c}} Y_{\mathrm{P}}$ (Total cellular activity): g 9-OH-AD per g harvested cell biomass per liter. $Y_{\mathrm{P}}=Y_{\mathrm{P} / \mathrm{X}} \cdot X$ 
concentrations. However, due to the phytosterol inhibition to microorganisms, the harvested cell biomass $(X)$ decreased. After considering the tradeoff between these opposing effects, the total cellular activity $\left(Y_{\mathrm{p}}\right)$ was used to select the most effective inducer concentration. We found that $Y_{\mathrm{p}}$ was highest $\left(7.5 \mathrm{~g} \mathrm{~L}^{-1}\right)$ using cells grown in the presence of $0.1 \mathrm{~g} \mathrm{~L}^{-1}$ phytosterol inducer, in contrast to the $Y_{\mathrm{p}}$ of $5.6 \mathrm{~g} \mathrm{~L}^{-1}$ observed when cells were grown in inducer-free medium.

\section{Optimizing operation parameter of resting cell bioconversion}

Initially, we varied the molarity and $\mathrm{pH}$ value of $\mathrm{PB}$ and found that a concentration of $20 \mathrm{mM} \mathrm{PB}$ and a $\mathrm{pH}$ value of 8 were optimal for bioconversion reactions (Supplementary Fig. S1 and Fig. S2). The

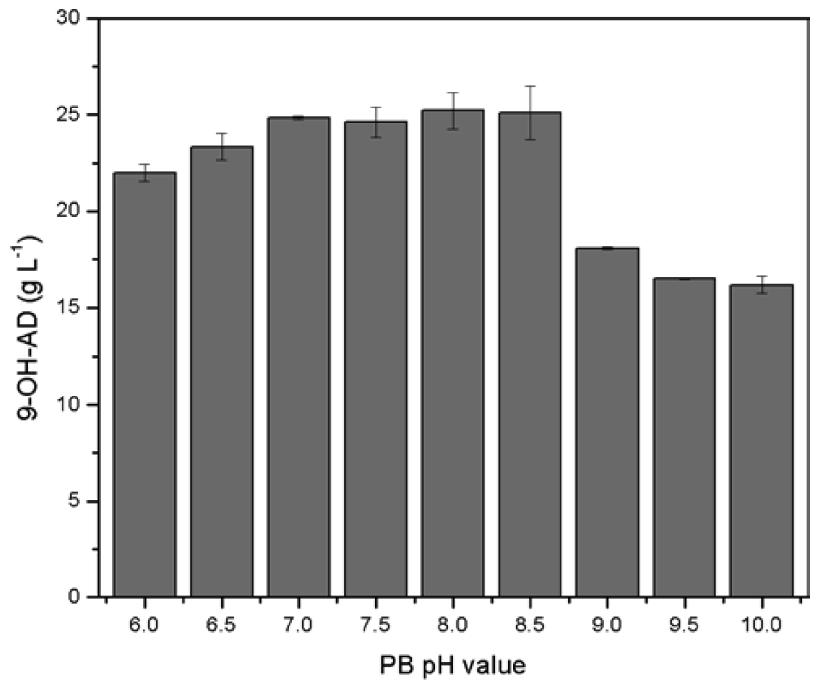

Fig. S 1 - Effects of $P B$ pH value on 9-OH-AD production using $15 \mathrm{~g} \mathrm{~L}^{-1} C D M, 50 \mathrm{~g} \mathrm{~L}^{-1}$ phytosterol, and a 1:1 molar ratio of $H P-\beta-C D /$ phytosterol

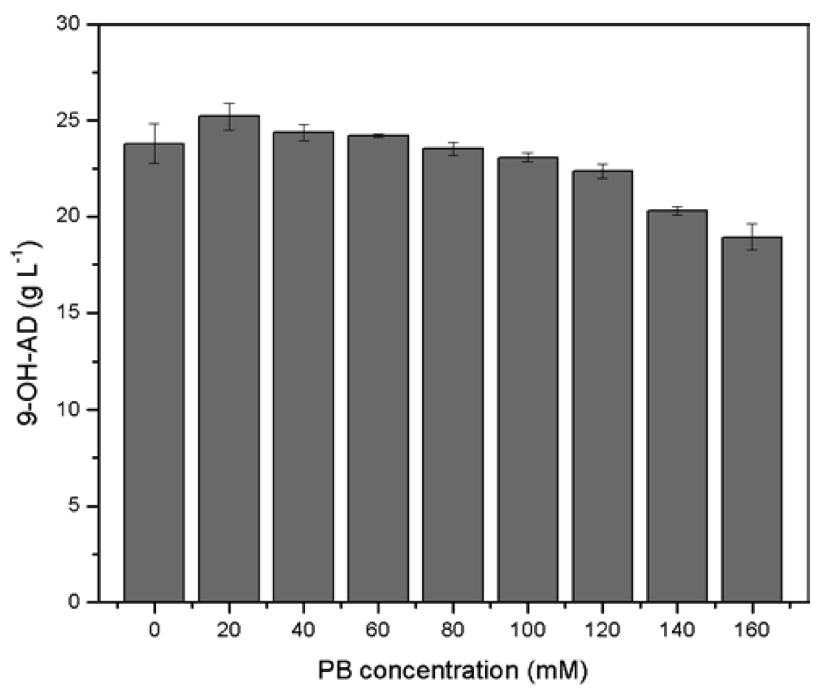

Fig. S 2 -Effects of $P B$ concentration on 9-OH-AD production using $15 \mathrm{~g} \mathrm{~L}^{-1} C D M, 50 \mathrm{~g} \mathrm{~L}^{-1}$ phytosterol, and a 1:1 molar ratio of $H P-\beta-C D /$ phytosterol phytosterol levels and cells densities were then investigated in the resting cell bioconversion system. To maximize the space-time yield, multilevel analyses of these two factors were performed, as shown in Table 2. Space-time yields increased with the increasing cell densities and phytosterol concentrations. The highest space-time yield of $9.4 \mathrm{~g} \mathrm{~L}^{-1} \mathrm{~d}^{-1}$ was obtained using $70 \mathrm{~g} \mathrm{~L}^{-1}$ phytosterol and a CDM of $30 \mathrm{~g} \mathrm{~L}^{-1}$ However, in cases where the phytosterol exceeded $90 \mathrm{~g} \mathrm{~L}^{-1}$ and the CDM exceeded $37.5 \mathrm{~g} \mathrm{~L}^{-1}$, the space-time yield decreased due to the substrate inhibition effect ${ }^{17}$ and poor oxygen transfer rates.

\begin{tabular}{c|c|c|c} 
Table 2 & $-\begin{array}{c}\text { Multilevel analysis of M. neoaurum NwIB-yV cell } \\
\text { densities and phytosterol concentrations on space- } \\
\text { time yields using the same HP- } \beta \text {-CD/phytosterol } \\
\text { molar ratio (1:1) }\end{array}$ \\
\hline \multirow{3}{*}{$\begin{array}{c}\text { CDM } \\
(\mathrm{g} \mathrm{L}-1)\end{array}$} & \multicolumn{4}{|c}{ Phytosterol $\left(\mathrm{g} \mathrm{L}^{-1}\right)$} \\
\cline { 2 - 4 } & 50 & 70 & 90 \\
\cline { 2 - 4 } & \multicolumn{4}{|c}{ space-time yield $\left(\mathrm{g} \mathrm{L}^{-1} \mathrm{~d}^{-1}\right)^{*}$} \\
\hline 7.5 & $5.2 \pm 0.2$ & $5.3 \pm 0.3$ & $5.2 \pm 0.2$ \\
15 & $6.4 \pm 0.2$ & $7.2 \pm 0.3$ & $4.9 \pm 0.2$ \\
22.5 & $8.4 \pm 0.1$ & $9.3 \pm 0.1$ & $3.7 \pm 0.2$ \\
30 & $8.7 \pm 0.1$ & $9.4 \pm 0.2$ & $3.3 \pm 0.2$ \\
37.5 & $8.5 \pm 0.2$ & $6.4 \pm 0.2$ & $2.2 \pm 0.1$ \\
\hline
\end{tabular}

"Space-time yield was calculated when 9-OH-AD production reached maximum levels

The dissolved oxygen level displays a crucial role in bioconversion reactions performed with a high substrate concentration and cell density. ${ }^{17}$ In the typical shake-flask experiment, the oxygen-supply conditions are determined by the system volume and the rotational speed. After adjusting the oxygen supply, the reaction rates showed strong correlations between changes in system volume and the rotational speed of the shaker (Supplementary Fig. S3 and Fig. S4).

\section{Resting cell bioconversion in the 5-L bioreactor}

In a 5-L stirred bioreactor, the supply of oxygen is determined by the agitation speed and aeration rate. During a resting cell bioconversion with M. neoaurum NwIB-yV cells performed for 4 days, 9-OH-AD production reached $36.4 \mathrm{~g} \mathrm{~L}^{-1}$, with a space-time yield of $9.1 \mathrm{~g} \mathrm{~L}^{-1} \mathrm{~d}^{-1}$ (Table 3 ) and with trace residual phytosterol when using $70 \mathrm{~g} \mathrm{~L}^{-1}$ phytosterol and $30 \mathrm{~g} \mathrm{~L}^{-1} \mathrm{CDM}$.

In addition to the previous study conducted by Yao et al. ${ }^{11}$ the productions of steroid metabolites using different reaction systems are summarized in Table 3. CD based systems, especially those using 


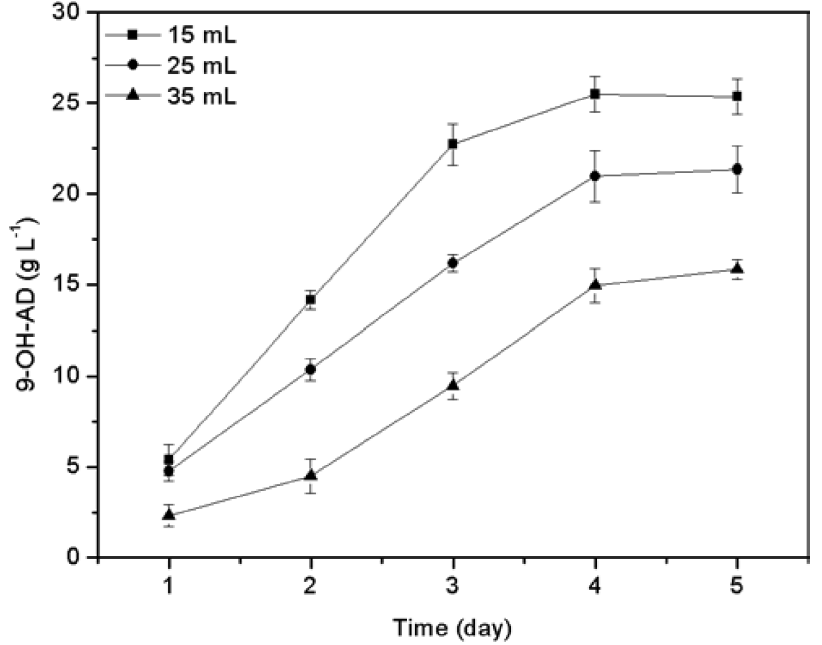

Fig. S 3 -Effects of system volume on 9-OH-AD production using $15 \mathrm{~g} \mathrm{~L}^{-1} C D M, 50 \mathrm{~g} \mathrm{~L}^{-1}$ phytosterol and a 1:1 molar ratio of $\mathrm{HP}-\beta-C D /$ phytosterol at $200 \mathrm{rpm}$

the $\mathrm{CD}$ derivatives $\mathrm{HP}-\beta$-CD and $\mathrm{MCD}$, have been widely applied in sterol bioconversion ${ }^{1}$ and have a higher reaction rate than that observed with other systems. Zhang et al. achieved, under an optimized molar ratio of $\mathrm{HP}-\beta-\mathrm{CD} /$ phytosterol, a space-time yield of $1.19 \mathrm{~g} \mathrm{~L}^{-1} \mathrm{~d}^{-1} \mathrm{AD} .^{5}$ In the presence of $\mathrm{MCD}$, a space-time yield of $2.53 \mathrm{~g} \mathrm{~L}^{-1} \mathrm{~d}^{-1} \mathrm{AD}$ was achieved by Andryushina et al. ${ }^{14}$ However, in a dimethyl formamide containing system, only $0.36 \mathrm{~g} \mathrm{~L}^{-1} \mathrm{~d}^{-1}$ of 9-OH-AD was obtained using sitosterol as sole substrate. ${ }^{18}$ Low process productivity and limited substrate concentrations were found using growing cell bioconversion. The use of resting cells as biocatalysts provides an efficient method for steroid production. Wang et al. reported the resting cell bio-

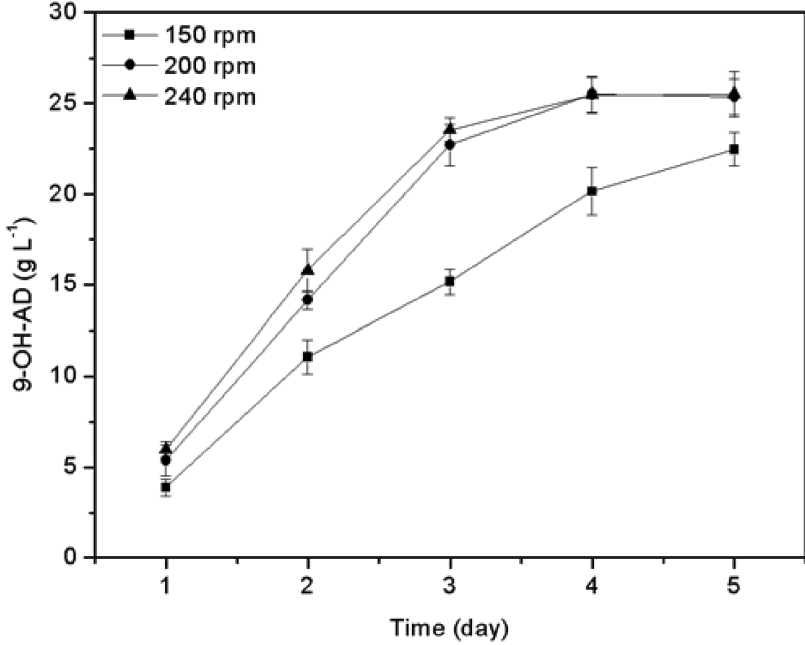

Fig. S 4 - Effects of rotational speed of the shaker on 9-OH-AD production using $15 \mathrm{~g} \mathrm{~L}^{-1} \mathrm{CDM}, 50 \mathrm{~g} \mathrm{~L}^{-1}$ phytosterol, and a 1:1 molar ratio of $\mathrm{HP}-\beta-C D /$ phytosterol in $15 \mathrm{~mL} P B$

conversion of $30 \mathrm{~g} \mathrm{~L}^{-1}$ phytosterol to ADD (2-2.4 $\mathrm{g} \mathrm{L}^{-1} \mathrm{~d}^{-1}$ ) with a cloud point system. ${ }^{12}$ Carvalho et al. studied resting cell bioconversion in liquid polymer-based systems, which produced approximately $0.58-0.73 \mathrm{~g} \mathrm{~L}^{-1} \mathrm{~d}^{-1} \mathrm{AD}$ from sitosterol. ${ }^{19}$

\section{Downstream processing and cells/HP- $\beta-C D$ recycle}

HP- $\beta$-CD is a relatively expensive compound and no cost-reduction or recycling procedures have been demonstrated. If HP- $\beta$-CD cannot be reused, its application in sterol bioconversion reactions would remain impractical. ${ }^{20}$ As shown in Fig. 2, the bioactivity of recycled cells was maintained for 3

Table 3 -Comparison of steroid metabolite production using sterol as substrate for different bioconversion systems

\begin{tabular}{|c|c|c|c|c|c|}
\hline $\begin{array}{c}\text { Culture } \\
\text { conditions }\end{array}$ & Strains & $\begin{array}{l}\text { Substrates } \\
\left(\mathrm{g} \mathrm{L}^{-1}\right)\end{array}$ & Strategy & $\begin{array}{c}\text { Major } \\
\text { metabolite }\end{array}$ & $\begin{array}{c}\text { Production/ } \\
\text { Space-time yield } \\
\left(\mathrm{g} \mathrm{L}^{-1} / \mathrm{g} \mathrm{L}^{-1} \mathrm{~d}^{-1}\right)\end{array}$ \\
\hline \multirow{5}{*}{$\begin{array}{l}\text { Growing } \\
\text { cells }\end{array}$} & M. neoaurum ZJUVN-085 & Phytosterol, 8.98 & $\mathrm{HP}-\beta-\mathrm{CD}$ & $\mathrm{AD}$ & $5.96 / 1.19$ \\
\hline & M. neoaurum ${ }^{14}$ & Phytosterol, 30 & MCD & $\mathrm{AD}$ & $15.2 / 2.53$ \\
\hline & Mycobacterium sp.2-4M ${ }^{18}$ & Sitosterol, 5 & $\mathrm{DMF}$ & 9-OH-AD & $1.8 / 0.36$ \\
\hline & M. neoaurum NwIB-yV $\mathrm{V}^{11}$ & Phytosterol, 15 & Tween 80 and silicon oil & 9-OH-AD & $7.33 / 1.22$ \\
\hline & M. neoaurum NwIB-01MS ${ }_{\text {ChoM2 }}{ }^{13^{*}}$ & Phytosterol, 15 & Tween 80 and silicon oil & ADD & $5.57 / 0.93-1.39$ \\
\hline \multirow{6}{*}{$\begin{array}{l}\text { Resting } \\
\text { cells }\end{array}$} & M. neoaurum NwIB-R10 ${ }_{\text {ChoM } 2}^{13 \#}$ & Phytosterol, 15 & Tween 80 and silicon oil & $\mathrm{AD}$ & $6.85 / 1.14-1.71$ \\
\hline & Mycobacterium sp. NRRL B-3805 19 & Sitosterol, 5 & Liquid polymer & $\mathrm{AD}$ & $2.9 / 0.58-0.73$ \\
\hline & Mycobacterium sp. NRRL B-3683 12 & Phytosterol, 30 & Cloud point system & $\mathrm{ADD}$ & $12 / 2-2.4$ \\
\hline & M. neoaurum NwIB-yV ${ }^{11}$ & Phytosterol, 70 & $\mathrm{HP}-\beta-\mathrm{CD}$ & 9-OH-AD & $36.4 / 9.1$ \\
\hline & M. neoaurum NwIB-01MS ${ }_{C h o M 2}{ }^{13}$ & Phytosterol, 70 & $\mathrm{HP}-\beta-\mathrm{CD}$ & ADD & $23.6 / 5.9$ \\
\hline & M. neoaurum NwIB-R10 ${ }_{\text {СhoM2 }}^{13}$ & Phytosterol, 70 & $\mathrm{HP}-\beta-\mathrm{CD}$ & $\mathrm{AD}$ & $23.2 / 5.8$ \\
\hline
\end{tabular}

"M. neoaurum NwIB-01MS ${ }_{\text {chom } 2}$ was developed by augmentation of ChoM2 and was better in ADD accumulation than M. neoaurum NwIB-01MS. ${ }^{\#}$ M. neoaurum NwIB-R10 ${ }_{\text {chom } 2}$, an AD-producing strain, was developed by augmentation of ChoM2 in M. neoaurum NwIB-R10. 


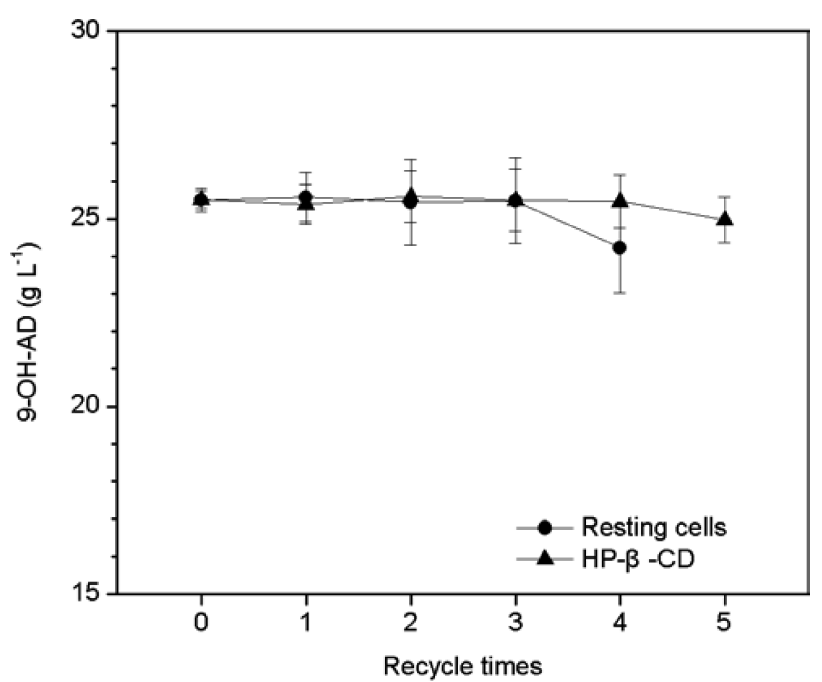

Fig. 2 - Repeated use of M. neoaurum NwIB-yV cells and $H P-\beta-C D$ in recycling bioconversion

subsequent cycles. During the fourth recycling phase, the product yield decreased to $90 \%$, due to lost cellular activity or reduced cell biomass. We were able to recycle HP- $\beta$-CD for at least 5 cycles. CDs and their derivatives can increase the bioavailability of hydrophobic compounds to microorganisms by forming host-guest complexes in the internal cavities of CDs. ${ }^{8,9}$ Then little decrease of $9-\mathrm{OH}-\mathrm{AD}$ production using recycled $\mathrm{HP}-\beta-\mathrm{CD}$ may result from the loss of $\mathrm{HP}-\beta-\mathrm{CD}$ during repeated bioconversion processes.

\section{Conclusion}

In this study, a bioconversion process was developed with resting cells as biocatalysts and HP- $\beta$-CD for substrate solubilization under non-sterile conditions. The availability of hydrophobic phytosterols was improved by the inclusion of HP- $\beta$-CD in the culture medium. The optimal molar ratio of HP- $\beta-\mathrm{CD} /$ phytosterol was $1: 1$. The bioconversion efficiency and overall production of 9-OH-AD were greatly improved. On the other hand, further product degradation could be inhibited via the formation of CD-steroid inclusion complexes. The use of resting cells as biocatalyst can be an effective way to improve the cell density. Cell growth medium containing phytosterol as an inducer positively improved cell activity. Cells cultured in the presence of $0.1 \mathrm{~g} \mathrm{~L}^{-1}$ inducer had the highest total cell activity. After optimization of bioconversion conditions, such as the $\mathrm{PB}$ concentration and $\mathrm{pH}$ value, cell density and phytosterol concentration, the 9-OH-AD production and space-time yield reached $36.4 \mathrm{~g} \mathrm{~L}^{-1}$ and $9.1 \mathrm{~g} \mathrm{~L}^{-1} \mathrm{~d}^{-1}$, respectively, under aerobic conditions in a 5-L bioreactor with M. neoaurum NwIB-yV cells. This resting cell bioconversion process was successfully applied for the production of ADD and AD by resting $M$. neoaurum $\mathrm{NwIB}-01 \mathrm{MS}_{\text {chom } 2}{ }^{13}$ and M. neoaurum NwIB- R10 chom2 ${ }^{13}$ cells, respectively, using conditions that were found to be optimal for 9-OH-AD production. Both the absolute production levels and space-time yield of 9-OH-AD, ADD and $\mathrm{AD}$ were higher than those reported in previous studies ${ }^{11,13}$, in an aqueous growing cell bioconversion system containing Tween 80 and silicon.

In addition, the reuse of resting cells 3 times and the reuse of HP- $\beta$-CD up to 5 times did not decrease bioconversion efficiency, enabling a significant cost reduction of phytosterol bioconversion. Moreover, the use of resting cells as biocatalyst may separate the bioconversion process from that of cell growth. Resting cell bioconversion can be run under non-sterile conditions resulting in lowered risks of bacterial contamination. ${ }^{12}$ Thus, it is reasonable to conclude that this resting cell bioconversion process can readily be applied in diverse areas of steroid metabolite production.

\section{ACKNOWLEDGMENT}

This study was supported by the National Natural Science Foundation of China (General Program, No. 21276083).

\section{References}

1. Donova, M. V., Egorova, O. V., Microbial steroid transformations: current state and prospects, Appl. Microbiol. Biotechnol. 94 (2012) 1423. doi: http://dx.doi.org/10.1007/s00253-012-4078-0

2. Fernandes, P., Cruz, A., Angelova, B., Pinheiro, H. M., Cabral, J. M. S., Microbial conversion of steroid compounds: recent developments, Enzyme Microb. Technol. 32 (2003) 688. doi: http://dx.doi.org/10.1016/S0141-0229(03)00029-2

3. Mutafov, S., Angelova, B., Avramova, T., Boyadjieva, L., Dimova, I., The inducibility of $9 \alpha$-steroid hydroxylating activity in resting Rhodococcus sp. cells Process Biochem. 32 (1997) 585. doi: http://dx.doi.org/10.1016/S0032-9592(97)00023-X

4. Sedlaczek, L., Smith, L. L., Biotransformations of Steroids, Crit. Rev. Biotechnol. 7 (1988) 187. doi: http://dx.doi.org/10.3109/07388558809146602

5. Zhang, X. Y., Peng, Y., SU, Z. R., Chen, Q. H., Ruan, H., $H e, G$. Q., Optimization of biotransformation from phytosterol to androstenedione by a mutant Mycobacterium neoaurum ZJUVN-08, J. Zhejiang Univ-Sci B (Biomed Biotechnol). 14 (2012) 132. doi: http://dx.doi.org/10.1631/jzus.B1200067

6. Heipieper, H. J., Neumann, G., Cornelissen, S., Meinhardt, $F$, Solvent-tolerant bacteria for biotransformations in twophase fermentation systems, Appl. Microbiol. Biotechnol. 74 (2007) 961. doi: http://dx.doi.org/10.1007/s00253-006-0833-4

7. Stefanov, S., Yankov, D., Beschkov, V., Biotransformation of phytosterols to androstenedione in two phase water-in-oil systems, Chem. Biochem. Eng. Q. 20 (2006) 421. 
8. Greenberg-Ofrath, N., Terespolosky, Y., Kahane, I., Bar, R., Cyclodextrins as carriers of cholesterol and fatty acids in cultivation of mycoplasmas, Appl. Environ. Microbiol. 59 (1993) 547.

9. Ma, Y. H., Wang, M., Fan, Z., Shen, Y. B., Zhang, L. T., The influence of host-guest inclusion complex formation on the biotransformation of cortisone acetate $\Delta 1$-dehydrogenation, J. Steroid Biochem. Mol. Biol. 117 (2009) 146. doi: http://dx.doi.org/10.1016/j.jsbmb.2009.08.007

10. Shen, Y. B., Wang, M., Li, H. N., Wang, Y. B., Luo, J. M., Influence of hydroxypropyl- $\beta$-cyclodextrin on phytosterol biotransformation by different strains of Mycobacterium neoaurum, J. Ind. Microbiol. Biotechnol. 39 (2012) 1253. doi: http://dx.doi.org/10.1007/s10295-012-1130-0

11. Yao, K., Xu, L. Q., Wang, F. Q., Wei, D. Z., Characterization and engineering of 3 -ketosteroid- $\Delta 1$-dehydrogenase and 3-ketosteroid-9 $\alpha$-hydroxylase in Mycobacterium neoaurum ATCC 25795 to produce $9 \alpha$-hydroxy-4-androstene-3,17-dione through the catabolism of sterols, Metab. Eng. 24 (2014) 181 . doi: http://dx.doi.org/10.1016/j.ymben.2014.05.005

12. Wang, Z. L., Zhao, F. S., Chen, D. J., Li, D. T., Biotransformation of phytosterol to produce androsta-diene-dione by resting cells of Mycobacterium in cloud point system, Process. Biochem. 41 (2006) 557.

doi: http://dx.doi.org/10.1016/j.procbio.2005.09.014

13. Yao, K., Wang, F. Q., Zhang, H. C., Wei, D. Z., Identification and engineering of cholesterol oxidases involved in the initial step of sterols catabolism in Mycobacterium neoaurum, Metab. Eng. 15 (2013) 75 doi: http://dx.doi.org/10.1016/j.ymben.2012.10.005

14. Andryushina, V. A., Rodina, N. V., Stytsenko, T. S., Huy, L., Druzhinina, A. V., Yaderetz, V. V., Voishvillo, N. E., Conversion of soybean sterols into 3,17-diketosteroids using actinobacteria Mycobacterium neoaurum, Pimelobacter simplex, and Rhodococcus erythropolis, Appl. Biochem. Microbiol. 47 (2011) 270. doi: http://dx.doi.org/10.1134/S0003683811030021

15. Khomutov, S. M., Sukhodolskaya, G. V., Donova, M. V., The inhibitory effect of cyclodextrin on the degradation of 9a-hydroxyandrost-4-ene-3, 17-dione by Mycobacterium sp. VKM Ac-1817D, Biocatal. Biotransfor. 25 (2007) 386. doi: http://dx.doi.org/10.1080/10242420701510510

16. Szentirrnai, A., Microbial physiology of sidechain degradation of sterols, J. Ind. Microbiol. 6 (1990) 101. doi: http://dx.doi.org/10.1007/BF01576429

17. Gao, X. Q., Feng, J. X., Hua, Q., Wei, D. Z., Wang, X. D., Investigation of factors affecting biotransformation of phytosterols to 9-hydroxyandrost-4-ene-3,-17-dione based on the HP- $\beta$-CD-resting cells reaction system, Biocatal. Biotransfor. 32 (2014) 343.

doi: http://dx.doi.org/10.3109/10242422.2014.976633

18. Donova, M. V., Gulevskaya, S. A., Dovbnya, D. V., Puntus, I. F., Mycobacterium sp. mutant strain producing $9 \alpha$-hydroxyandrostenedione from sitosterol, Appl. Microbiol. Biotechnol. 67 (2005) 671 doi: http://dx.doi.org/10.1007/s00253-004-1808-y

19. Carvalho, F., Marques, M. P. C., de Carvalho, C., Cabral, J. M. S., Fernandes, P., Sitosterol bioconversion with resting cells in liquid polymer based systems, Bioresour. Technol. 100 (2009) 4050. doi: http://dx.doi.org/10.1016/j.biortech.2009.03.044

20. Moriwaki, C., Costa, G. L., Ferracini, C. N., de Moraes, F. F., Zanin, G. M., Pineda, E. A. G., Matioli, G., Enhancement of solubility of albendazole by complexation with $\beta$-cyclodextrin, Braz. J. Chem. Eng. 25 (2008) 255. doi: http://dx.doi.org/10.1590/S0104-66322008000200005 